\title{
Subtitling as a Didactic Tool. A Teacher Training Experience
}

\author{
Isabel López Cirugeda and Raquel Sánchez Ruiz \\ Universidad de Castilla-La Mancha
}

Received: 22 March 2012 / Accepted: 05 May 2012

ISSN: $1697-7467$

\begin{abstract}
This paper seeks to show the evolution and results of a task-based project, carried out in groups in the framework of a class of Education university students, consisting of the cooperative creation of homemade subtitled English-speaking films of approximately five minutes each aimed at children. Their assessment was based not only on their proposals and their didactic appropriateness and linguistic rightness, but also in terms of their performance as a cooperative team, which was registered through final reports.

Through this experience, the teachers-to-be were offered the opportunity to create their own teaching material and to deal with video editing and the use of subtitles as part of their ICT training.

Keywords: audiovisual language, foreign language teaching, short films for children, subtitles, ICT training.

El subtitulado como herramienta didáctica. Una experiencia de formación docente

RESUMEN: Este artículo muestra el desarrollo y resultados de una tarea grupal programada para una clase de grado de Educación Primaria consistente en la elaboración de vídeos en lengua inglesa subtitulados, de contenido didáctico y de aproximadamente cinco minutos de duración. Los alumnos fueron evaluados tanto por su propuesta, especialmente en términos de su adaptación al currículum de Educación Primaria y de su corrección lingüística, como por su actuación como equipo dentro de los parámetros del trabajo cooperativo, mediante la entrega de informes finales.

En esta experiencia, los futuros maestros tuvieron la ocasión de crear su propio material didáctico, además de completar su formación en nuevas tecnologías a través de la edición de vídeo y subtitulado.

Palabras clave: lenguaje audiovisual, enseñanza de idiomas modernos, cortos infantiles, subtítulos, aprendizaje nuevas tecnologías.
\end{abstract}

\section{INTRODUCTION}

The ever-increasing importance of the audiovisual language in every aspect of today's society has significantly changed educational methods and resources, especially in the frame of modern language teaching, as image and sound promote the communication in the classroom the whole session is seeking for. In this article, our purpose is to show an experiment carried out among fifty-four second year students of the undergraduate degree in Primary 
Education in the Faculty of Education in Albacete (Universidad de Castilla-La Mancha). This task was developed within the subject English Language and Didactics II, where students are expected to communicate in English at a B1-B2 level of the Common European Framework of Reference for Languages: Learning, Teaching, Assessment (CEFR) ${ }^{1}$ and are supposed to be able to create and acquire didactic resources to use in a Primary classroom.

As a consequence of meeting the Bologna European Higher Education adaptation requirements, the curriculum of students at the Faculty of Education has evolved from a specialist to a generalist profile. This implies that every student must accomplish two course units in Modern Languages, in our case English Language and Didactics I \& II, for both the undergraduate degrees of Primary and Early Childhood Education, aimed to enable them to teach English, regardless of whether they follow their English studies through a minor in that language or not, a circumstance which certainly demands an optimization of the classroom tasks in terms of both language acquisition and didactic training.

In the particular case of English Language and Didactics II, students were asked to design a complete class unit for a fourth grade of Primary class in accordance with the legislation in force. Our project consisted of the cooperative production of an up-to-five minute audiovisual recording suitable to be used as a didactic resource for that unit. Intralingual subtitles had to be added to their productions, as it was our aim to follow the European Commission recommendation of using «foreign language learning methods based on the creation of subtitles by students and pupils» (2011: 28) due to their success in previous experiences to promote multilingualism ${ }^{2}$.

The objectives of our project were divided into four different parameters: Didactics, the Communicative Competence, the Digital and Information Processing Competence and Cooperative Work, so that the assessment was based on competences (annex 1). The aims regarding Didactics were both to provide our students with the chance to create their own brand-new teaching material responding to the needs and tastes of a child audience and to apply their didactic knowledge through the introduction of aspects responding to what are defined as the basic competences of Primary Education ${ }^{3}$. Those related to the Communicative Competence included planning a suitable script showing a correct oral and written production in the L2. The objectives related to the Information and Communication Technology (hereafter ICT) Competence were to learn how to use subtitling tools so as to integrate them into their language teaching practice in Primary education and to deal with video and audio

\footnotetext{
${ }^{1}$ The Common European Framework of Reference for Languages (CEFR) is available from: http:// www.coe.int/t/dg4/linguistic/cadre_en.asp, accessed 21 May, 2012.

${ }^{2}$ The European Commission engaged on a year-long study involving 33 European countries aimed to analyse the impact of subtitling on multilingualism and multiculturalism. The final report, Study on the use of Subtitling. The potential of subtitling to encourage foreign language learning and improve the mastery of foreign languages is available at: http://eacea.ec.europa.eu/llp/studies/study_on_the_use_of_subtitling_en.php, accessed 21 May, 2012.

${ }^{3}$ The European Commission of Education and the Spanish Education Act (LOE, 2006) establishes eight basic competences that are not included in the curricular areas but must be worked on in all of them. Those are: Communicative Competence, Mathematical Competence, Competence in Knowledge of and Interaction with the World, Digital and Information Processing Competence, Social and Civic Competence, Cultural and Artistic Competence, Learning to Learn Competence and Autonomy and Personal Initiative Competence. Moreover, Castilla-La Mancha's 68/2007 Decree establishes another one, which is Emotional Competence.
} 
recording and editing, as well as slide presentations. Students were also required to provide their self-assessment on Cooperative Work by commenting their own performance as a team by writing a brief guided report, which was filled and virtually sent to Moodle platform individually in an attempt to guarantee sincere answers (annex 2). Apart from that, another report, this time in groups, was aimed to reveal the major difficulties found at all stages of the project in order to evaluate the whole process and be able to make amendments for future similar projects (annex 3).

The present proposal was founded on the consideration of the European Commission of subtitling as a valuable didactic tool, as it helps enhance foreign language skills and can also create awareness of language and cultural diversity as well as provide motivation to learn languages (2011: 28). By acknowledging this belief, we estimated as most useful to provide our students with the right materials and learning processes to use in their future careers as teachers in real schools. Moreover, this kind of task, involving the addition of subtitles acts, as Talaván says, as «a functional and interactive exercise that allows students to share their work with their peers in a virtual learning environment» (2010b: 286), which meant to produce extra teaching-applicable benefits in the short-term (by having to explain the knowledge acquired through the process to their mates).

Some other anticipated benefits were linked to group work, which, as De la Cruz Cabanillas and Tejedor Martínez (forthcoming) state, provide the opportunity to improve communication techniques and decision-making skills, so that results could and can be implemented as a combination of language and subject teaching, tasks also encouraged cooperative work and critical thinking and, finally, learners were exposed to real world situations and authentic materials and tools.

\section{Stages of the PRoject}

The development of the project was divided into four different parts (as seen on Figure 1): the initial stage, where the groups were formed and the level and topic assigned; the second one, the researching stage, where students had to learn about the legal Education framework, to search for materials and bibliography, to attend several useful workshops on subtitling and ICT and to foresee solutions to any problems that may arise; the third one, the production stage, where their scripts were planned and written, and their videos designed, which also implied the use of recording and subtitling tools. Finally, in the postproduction stage, the resulting videos were edited, their language production was reviewed and all the products were presented in front of the rest of the class but, then, integrated into their class units. 


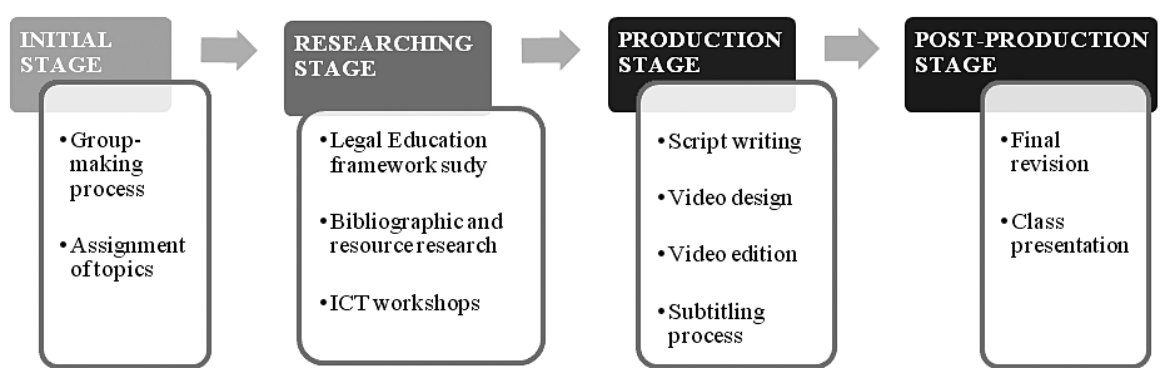

Figure 1

\subsection{Initial stage}

As mentioned above, students had to prepare a class unit for the same level, namely fourth grade of Primary. Therefore, in the first days of the academic year, groups of four members were formed according to their own personal preferences, that is, the students chose specifically those other mates they wanted to work with, as all of them would have the same mark at the end. Afterwards, the topics for their class units were also assigned; they were selected by the teachers and randomly distributed among the students from a previously-prepared list, which contained the most common topics taught in Primary school ${ }^{4}$. The instructions deliberately referred to a recording and not to a video in order to avoid constraint to just one specific format or limitation of the participants' creativity.

The students experienced some problems with regard to this phase, especially with respect to cooperative work, since they were rather reluctant to interact. As it was later stated in their evaluation and self-evaluation reports, the most difficult aspect was to choose the appropriate mates since their being assigned a common mark significantly conditioned their decisions. This also provoked qualitative differences, because the most hard-working, successful, outstanding students obviously chose to work together and, therefore, eventually obtained excellent or at least quite good results; and those with more difficulties in English or who were less pro-active found themselves obliged to work together and so attained worse results and marks.

\subsection{Researching Stage}

As its name indicates, at this stage students had to investigate and become knowledgeable about several issues so as to do their job properly. At first they had to look for different materials such as reference books and useful webpages, both related to English teaching in Primary school and to ICT and subtitling tools such as software tutorials and

\footnotetext{
${ }^{4}$ The topics included on this list were in alphabetical order: animals, autumn, Christmas, clothes, family, food and drinks, house, holidays/festivities, means of transport, nationalities, new technologies, parts of the body, recycling, spring, summer, sports, the city/the countryside, the media, weather and winter.
} 
forums. Then, they had to select the tales, characters, and stories that they wanted to use in their projects.

Besides, students were offered the abovementioned workshops which covered the essentials to create the subtitles needed for the development of the project. General subtitling norms were explained: in most countries, no more than two lines of text should be displayed at a time, with a maximum of 35 characters and spaces on each one of them, due to the fact that our listening skills are much quicker than our reading abilities (Díaz Cintas, 1995: 11-13), that they should «remain on screen for a minimum of two and a maximum of seven seconds» (Hatim and Mason, 1997: 65) and that «as a rule, they are placed at the bottom of the picture and are either centred or left-aligned» (Condinho Bravo, 2009: 82). All these rules had to be adapted by our students to fulfil the principle of maximum legibility (Ivarsson and Carroll, 1998: 39), as the age of the target audience (8-year-olds) highly conditioned the length and timing for those lines.

The relevance of subtitling for the acquisition and learning of a foreign language was highlighted for, as Talaván (2010: 295) says,

the use of subtitling and subtitles combines a series of qualities that motivate, foster and facilitate the development of oral comprehension: it is recreational, familiar and dynamic, utilises multiple codes, and makes the achievement of this receptive skill easier, both individually and collaboratively.

As stated before, the whole project was based on a belief in the beneficial effects of getting pupils accustomed to subtitles in class so that they learn to also expect and even ask for them outside school. Since Spain belongs to a dubbing culture, the sooner children approach subtitles, the better for them to overcome their fear of watching television or a film in a foreign language with subtitles.

In addition, students were also provided with several other workshops on ICT, which included slide presentation management at an elementary and intermediate level, and specific software handling. They were taught how to use both freeware and trial versions to cut sound bites and save them in MP3 format (MP3 Cut Direct) and to convert formats from almost any source to AVI (AVI Video Converter, Leawo Free AVI Converter) or to MPG or MPEG (Blaze Media Pro). They were also shown how to utilise particular subtitling tools such as AVI Subtitler, DivXLand Media Subtitler and Subtitle workshop to add subtitles to already recorded videos, which had been previously saved in the appropriate format; as well as Pocket DivX Encoder and Virtualdub to combine subtitles in .srt and .ssa format and .mpeg and .avi videos ${ }^{5}$

${ }^{5}$ MP3 Cut Direct, freeware available from: http://mp3directcut.softonic.com/descargar, accessed 21 May, 2012.

AVI Video Converter, trial version available from: http://www.video-converter.net/download.htm or http:// descargar.portalprogramas.com/AVI-Video-Converter.html, accessed 21 May, 2012.

Leawo Free AVI Converter, freeware, which converts to AVI, but also to MPG, MOV, WMV and MP4 and can be used to join video files together as well. Available from: http://www.moyeamedia.com/videoconverter/avi-converter.html, accessed 21 May, 2012.

Blaze Media Pro, trial version available from: http://www.blazemp.com/downloads.html, accessed 21 May, 2012. 
In the same vein, in this stage, students also had to investigate the legal framework concerning Education at different levels, that is, in the European Union by means of the CEFR, the Spanish Education Act (LOE), and the regional curriculum based on the national one standardised by our Autonomous Community, Castilla-La Mancha, under the Decree 68/2007. All this was required to enable students to create appropriate activities which met national and regional objectives, competences and results suitable for the second cycle of Primary education in Spain, for fourth grade in particular, and to coherently integrate them first into their class units and then into their syllabi for the whole year.

In this phase, students also had some tutorials with both teachers, and were encouraged to consult different non-university experts in several fields, such as didactics, film production and ICT, which some of them did. Students also had to periodically present written reports and oral presentations showing the development of their projects, so that it could be positively evaluated, and in order to obtain feedback to improve their production and to solve problems either related to the English language, to didactics or subtitling.

At this point, further problems arose. In this case, they were related to students' computer illiteracy, for some of them were disinclined to use new software they had never heard of before; and also to their workload, since the deadline of the project was at the end of May. As they had many other projects to present for different subjects and exams to take, they tended to complain. It was also rather difficult to fix suitable timetables for everyone as they had to attend in groups of four for workshops, seminars and tutorials.

\subsection{Production stage}

Four steps had to be followed at this stage: first the script design; then the video or presentation design; after that, the recording; and finally the subtitling process. In the first step, everything had to be arranged, that is, the characters who were going to appear (the storyboard, the story plan surrounding them, their physical appearance, clothes, attitudes, voices, etc.), the drawings for those who used presentations (people/animals/things, colours, face expressions, gestures, voices, animated/state figures, etc.), and obviously writing the story to be told according to the assigned topic, relating the characters with the tale, with an ordered and well-planned organisation and considering the limitations of English but also cultural knowledge of fourth graders in Primary.

In the video or presentation design stage, the storyboard and the setting had to be decided. In the case of the presentations, slides and drawings were used; but in the case of videos, the recording location had to be chosen, taking into account space, light and noise so that the voices could be intelligible. Some of our students recorded their videos scene by

AVI Subtitler, freeware available from: http://www.softpedia.com/get/Multimedia/Video/Other-VIDEOTools/AVI-Subtitler.shtml, accessed 21 May, 2012.

DivXLand Media Subtitler, freeware available from: http://www.divxland.org/esp/subtitler.php, accessed 21 May, 2012.

Subtitle Workshop, freeware available from: http://subtitle-workshop.en.softonic.com/, accessed 21 May, 2012.

Pocket DivX Encoder, freeware available from: http://www.pocketdivxencoder.net/EN_index.htm, accessed 21 May, 2012.

Virtualdub, freeware available from: http://virtualdub.uptodown.com/, accessed 21 May, 2012. 
scene and then put them together. Obviously, and in both cases, stories had to be ordered in a logical and understandable way.

Then it was time for the recording, that is, video making and slide presentations so as to obtain the final product to create a specific activity and to integrate it into a unit. At this point, it was important to take into consideration that students as non-experts used domestic tools but also programmes and software which were, as previously mentioned, freeware and on some occasions trial versions, but never highly specialised or professional ones.

This was followed by the subtitling process, where students were required to add intralingual English subtitles to their recordings, whose audio was entirely in English. In order to do this, previously mentioned specific software and formats were needed.

Some of the problems which appeared in this phase were related to: a) the video recordings, with regard to time for the students in a group were not always free to meet at the same time and space since many of them were filmed in the students' own houses, and dealing with external noise and interruptions; b) software handling issues, especially where subtitling and saving in the appropriate format were concerned; c) and because they were not experts, not even translators, and due to the fact that they had no prior experience of creating subtitles they had scarce knowledge of this. Consequently, although some of them did watch television or films in their original language with subtitles on a regular basis, for most of them it was relatively difficult to follow and apply the basic rules of subtitling in practice, especially in regard to all those constraints explained in the 2.2. Researching stage section.

\subsection{Post-production stage}

In the last phase of the project three things had to be attended to: the editing of the video, the review of the language and the classroom presentation. With regard to the editing, once the video was already recorded, it had to be saved in the appropriate format for the programme to be used to play it later. In the case of presentations, the format also needed to be checked, as not everyone used PowerPoint (.ppt), but also OpenOffice Impress (.odp). In addition, aspects of presentation needed to be reviewed (tables, charts, figures, lines, font size and type, etc.).

Students also had to check that their videos were well recorded, especially paying attention to the quality both of the images and audio; synchronization between speech, scene and subtitles had to be carefully taken into account. They had to test that the video, audio and subtitles worked perfectly together and could be seen at the same time on the screen. In the cases where this did not happen, formats had to be converted in order to connect video, audio and/or subtitles with the proper software.

As already mentioned, our students were supposed to have a B1 English level at the beginning of the academic year and then to acquire a B1-B2 during the course. However, language was a great problem for some of them. This is why they were strongly encouraged to review their English production before presenting their projects to teachers. Even so, serious misspelling and grammar mistakes were seen, as well as punctuation errors, which could detract from the meaning of the subtitles, especially considering the audience here (the students' classmates), who have a tendency to lose their faith in subtitles if the meaning 
is not clear. To try to avoid this, a few students demanded tuition every time they thought they needed to in order to clear up any problems or queries they had.

Apart from the above, the students had to get prepared for their classroom presentations, where every group had to show their videos or presentations integrated into their class units. Again, the information had to be shown in a logical and clear way and in simple but accurate English so as to be understood by the rest of their classmates. Since it was an oral presentation with an audience of around sixty people, students also had to think about achieving the appropriate tone of voice and rhythm, as well as positioning themselves so that the audience could hear them clearly whilst at the same time being able to see the board or presentation. It was important for them to move as little as possible during their presentations in order not to cause distraction or to be the main focus of attention to the detriment of the data projector and screen.

At this stage further problems arose, for example those related to software handling, as students had to pay attention when saving videos, audio and subtitles so as to choose the appropriate format; others related to language, as some groups had great difficulties carrying out their projects due to their poor English level, especially with regard to pronunciation; others related to stage fright, because students are not used to talking in public and they did not feel self-confident when doing it, even though the presentations were performed in groups of four; and finally problems related to a variety of didactic doubts regarding the suitability of the activities to the level of different pupils and the design of a lesson plan in particular and of a year-long syllabus in general.

\section{Results}

Some specific projects are described below, alphabetically ordered by their title and with details of the skills and objectives of the activities developed around the recordings.

The first project was called "Autumn's Tale» and it was to be included into the class unit Autumn. The activity integrated a video performed by the members of the group with subtitles, so the skills worked on were listening and reading. After reading and listening to the recording three times, pupils had to fill in gaps with vocabulary which had been previously explained on the blackboard. Therefore, the objectives of the activity were to check pupils' listening and reading comprehension, as well as whether they had understood and acquired the new vocabulary.

The second one was «The Chestnut Seller», which was also included in a class unit entitled Autumn, but that of another group. The proposal consisted of a slide presentation containing drawings taken from an original tale, a script in English written by the students themselves and their recorded voices, along with their corresponding subtitles. Students had to listen to the story twice at the same time as reading the subtitles and looking at the drawings. Finally, they had to order the pictures as they had appeared on the screen. The objective of this activity was to review the grammar structures and vocabulary studied in the class unit through listening and reading and testing their attention via a motivating and relaxing activity.

The third one was «It's Christmas Time», which was integrated into the Holidays and Festivities class unit. It was an interactive tale on a slide presentation, which included 
drawings taken from the internet, typical Christmas songs and the students' own voices and subtitles. The teacher played the first slide and then pupils had to choose one together by clicking one of the two options that our students had prepared, which could result into two different stories and subsequently endings. The objectives of the activities were to promote pupils' participation and oral interaction by means of a motivating and entertaining activity and, at the same time, to enhance their listening and reading skills.

«Halloween» was the title of the fourth recording, which was created to cover a part of the Autumn class unit mentioned above. The task was to listen to a video again performed by all the members of the group where vocabulary, as well as several syntactic structures, were explained. At the end of the video, pupils had to work in groups and prepare a short play using the vocabulary and grammar previously shown and then perform it in front of the rest of the class. Here, the five skills were worked on, since they had to pay attention to the video (listening) and at the same time to the subtitles (reading), they had to write a script (writing) discussing and making decisions in English with the rest of the team (oral interaction) and performing in class (oral production).

The fifth project was «Let's Buy Some Fruit» and was part of the Food and Drinks class unit. It was composed of a slide presentation, with drawings which the students made and coloured themselves, their own voices imitating different accents: British, American and Arabic and subtitles. The objectives were to check students' listening and reading comprehension by means of short-answer questions and the ordering of sentences, whilst at the same time making students aware of the different English accents in a multicultural society. In the video, eating healthily, especially fruit and vegetables, was promoted among young children, too.

Another recording was «My Favourite Gadget», incorporated into the class unit called New Technologies. This activity consisted of a video performed by the students themselves where different scenes were recorded and where a specific structure was drilled, as the objective of it was to teach the pupils that structure and make them repeat it by also using the vocabulary seen in the whole unit and thus also practising their oral production skills.

The last one was «The Appropriate Container», included in the class unit Recycling. The activity consisted of a video in which the students themselves explained how to recycle properly by utilizing homemade cardboard containers imitating real ones; pictures of different types of rubbish stuck on cards were provided to pupils to be put into these containers. Pupils were divided into groups and cards were dealt to them; they were given five minutes to discuss, separate and classify their rubbish to be taken out, so the main skill worked on in this task was oral interaction.

Aside from the recording itself, the project included a report commenting and reflecting on the main problems encountered. These reports have been summarized and their main and common outcomes are described as follows:

Students had different problems with subtitles: a) Shifting from speech to writing, since some students used different accents and dialects in their recording, as well as emphasis in intonation, which was impossible to reproduce when adding subtitles. Turn-taking was also difficult for them especially when, to indicate it, three lines of text were needed, as it was not automatic as in speech, where dissimilar tones or voices are used; b) Physical constraints were also a difficulty, because sometimes adjusting to no more than thirty five characters each line and no more than two lines per shot or slide was not an easy task. This meant 
that the students had to summarize their scripts when writing them. Therefore, inevitably, there was a degree of loss of meaning; c) An added obstacle was that the subtitles had to be suitable for fourth graders of Primary, which meant that they had to contain short and simple messages, so redundancy was very often present; d) Eventually, technical and formal aspects were also involved, that is, synchronization; subtitles had to fit and it was extremely important to take into consideration the pace of the soundtrack, dialogue and subtitles, being the most common complication matching visual images to subtitles.

\section{Conclusions}

After analysing all the students' projects, the conclusions were drawn into a SWOT analysis which could be described as follows:

With regard to the strengths of the projects, students were able to design their own resources and homemade material, with quite creative and original ideas which also resulted in motivational material for both the teachers-to-be as they were fully involved in the activities and, most likely, their prospective pupils as Primary students find it highly entertaining to see their teachers on the screen and to participate in different kinds of activities from those that they normally do in class with textbooks. Moreover, almost all groups were aware of the European, national and regional curricula, and so created different types of activities covering all the skills and competences, suitable for Primary and in accordance with the topic which they were assigned. Considering our students were not experts and do not specialize in translation, their subtitles conveyed the correct sense and meaning. One final strength of their projects was that their results showed a positive approach to ICT and subtitling as a tool for their teaching career and as a means to integrate competences such as the Digital and Information Processing Competence and the Communicative Competence, at the same time as being a good way to improve pupils' foreign language learning and acquisition through entertainment.

On the other hand, several weaknesses were found as well, especially in relation to computer illiteracy handling new software and programmes, which sometimes lead to discouragement. In fact, some of our students had to overcome their fear of using technology (technophobia). Moreover, several problems with respect to licenses also arose. Since only freeware and trial versions were used, not everything could be done with the same programmes, contrary to what would have happened if licensed and purchased software had been used. Poor language level and insufficient didactic background were also apparent in their activities and, therefore, in their recordings. Because students were inexperienced in subtitling, some issues such as font types and size along with synchronization between image, action, speech and written text were neither completely appropriate nor accurate in almost every project. Finally, as students had also many other tasks and essays to complete for other subjects, they had some problems meeting deadlines and some of them had minor delays.

All things considered, the project could be seen as reasonably successful and, therefore, a revised version of it (using licensed software, more workshops on ICT coordinated with other subjects where it can be used as well and subtitling) has been included in the outline for this course unit for the next academic year. Despite being a high-demanding task, a noticeable degree of satisfaction was shown by the students. Only time will tell if, for some of 
them, this sort of experience becomes a habitual practice in their teaching careers, resulting in long-term use of creative subtitled amateur film as a language teaching resource.

\section{REFERENCES}

Condinho Bravo, M. C. (2009). Putting the Reader in the Picture: Screen Translation and ForeignLanguage Learning. Tarragona: Universitat Rovira i Virgili.

Cruz Cabanillas, I. de la and Tejedor Martínez, C. (2011). «Integrating ICT in Second Language Teaching and Learning». Paper presented at Adquisición y aprendizaje de la lengua extranjera. Aspectos metodológicos y de investigación: Cursos de verano (Universidad de Castilla-La Mancha, 6-8 July 2011).

Delabastita, D. (1989). «Translation and Mass Communication: Film and TV Translation as Evidence of Cultural Dynamics», in Babel, 35:4: 193-218.

Delabastita, D. (ed.) (1997). Traductio. Essays on Punning and Translation. Manchester: St. Jerome Publishing.

Díaz Cintas, J. (1995). «El subtitulado como técnica docente», in Vida Hispánica 12: 10-14.

Díaz Cintas, J. (2001). La traducción audiovisual: El subtitulado. Salamanca: Almar.

Díaz Cintas, J. (2004). «Subtitling. The long journey to academic acknowledgement», in The Journal of Specialised Translation 1: 50-70.

Díaz Cintas, J. (2003). Teoría y práctica de la subtitulación: inglés/español (With a DVD containing a subtitling simulation programme and exercises). Barcelona: Ariel.

Díaz Cintas, J. and Muñoz Sánchez, P. (2006). «Fansubs: Audiovisual translations in an amateur environment», in The Journal of Specialised Translation 6: 37-52.

D'Ydewalle, G. (2002). «Foreign-language acquisition by watching subtitled television programs», in Journal of Foreign Language Education and Research 12: 59-77.

European Commission (2011): Study on the use of Subtitling. The potential of subtitling to encourage foreign language learning and improve the mastery of foreign languages, http://eacea. ec.europa.eu/llp/studies/study_on_the_use_of_subtitling_en.php, accessed 21 May, 2012.

Gambier, Y. \& Gottlieb, H. (eds.) (2001), (Multi)Media Translation. Concepts, Practices and Research (selected papers from the Multimedia \& Translation seminar, Misano, September 1997 and the second Languages and the Media conference, Berlin, October 1998). Amsterdam: John Benjamin's.

Hatim, B. and Mason, I. (1997). The Translator as Communicator. London and New York: Routledge.

Ivarsson, J. and Carroll, M. (1998). Subtitling. Simrishamn: TransEdit.

Lever, H. J.: MA in Translation and Interpreting: 50-70, available from: http://www.peak-translations. co.uk/pdfs/Subtitling.pdf, accessed 21 May, 2012.

Remael, A. (2004). «A place for film dialogue analysis in subtitling courses». In P. Orero (ed.) Topics in Audiovisual Translation. Amsterdam and Philadelphia: John Benjamins, 103-126.

Talaván, N. (2010). «Audiovisual translation and foreign language learning: The case of subtitling», in Caballero, R. and Pinar, M. J. (eds.) Ways and modes of human communication. Cuenca: Ediciones de la Universidad de Castilla-La Mancha.

Talaván, N. (2010b). «Subtitling as a Task and Subtitles as Support: Pedagogical Applications», in J. Díaz Cintas, A. Matamala, and J. Neves (eds.) New Insights into Audiovisual Translation and Media Accessibility. Amsterdam: Rodopi. 285-299.

Talaván, N. (2006). «Using subtitles to enhance foreign language learning», in Porta Linguarum 6: 41-52. 
Common European Framework of Reference for Languages: Learning, Teaching, Assessment (CEFR). Available from: http://www.coe.int/t/dg4/linguistic/cadre_en.asp, accessed 21 May, 2012.

Decree 68/2007, May 29 $9^{\text {th }}$, establishing and regulating the Curriculum for Primary Education in the Autonomous Community of Castilla-La Mancha. DOCM 1-06-2007: 14759-14816.

Organic Law of Education (LOE) 272006 May 3 ${ }^{\text {rd }}$. BOE 4-05-2006: 17158-17207. 


\section{ANNEXES}

\section{Annex 1: Assessment rubric}

\begin{tabular}{|c|c|c|c|c|}
\hline \multirow[b]{2}{*}{$\begin{array}{l}\text { ASSESSMENT } \\
\text { CRITERIA }\end{array}$} & \multicolumn{4}{|l|}{ INDICATORS AND SCORE } \\
\hline & $\begin{array}{l}\text { Excellent } \\
(10-9)\end{array}$ & $\begin{array}{l}\text { Good } \\
(8,9-7)\end{array}$ & $\begin{array}{l}\text { Fair } \\
(6,9-5)\end{array}$ & $\begin{array}{l}\text { Poor } \\
(4,9-0)\end{array}$ \\
\hline $\begin{array}{l}\text { COOPERATIVE } \\
\text { GROUP WORK }\end{array}$ & $\begin{array}{l}\text { The group is } \\
\text { integrated and designs } \\
\text { their own resources } \\
\text { and homemade } \\
\text { material. The tasks } \\
\text { and roles are equally } \\
\text { and clearly } \\
\text { distributed. } \\
\text { All the members } \\
\text { contribute with quite } \\
\text { creative and original } \\
\text { ideas. } \\
\text { All the members try to } \\
\text { motivate the whole } \\
\text { group and have a } \\
\text { positive attitude. } \\
\text { All the members meet } \\
\text { regularly and work } \\
\text { previously at home to } \\
\text { save time at the } \\
\text { meetings. }\end{array}$ & $\begin{array}{l}\text { The group is mostly } \\
\text { integrated and } \\
\text { designs their own } \\
\text { resources and } \\
\text { homemade material. } \\
\text { The tasks and roles } \\
\text { are equally } \\
\text { distributed. } \\
\text { Most of the members } \\
\text { contribute with quite } \\
\text { creative and original } \\
\text { ideas. } \\
\text { Most of the members } \\
\text { try to motivate the } \\
\text { whole group and } \\
\text { have a positive } \\
\text { attitude. } \\
\text { All the members } \\
\text { meet regularly and } \\
\text { some prepare ideas at } \\
\text { home to be worked at } \\
\text { the meetings. }\end{array}$ & $\begin{array}{l}\text { The group is } \\
\text { integrated and designs } \\
\text { their own resources, } \\
\text { although not all their } \\
\text { material was } \\
\text { homemade. Most of } \\
\text { the tasks or roles are } \\
\text { either equally or } \\
\text { clearly distributed. } \\
\text { Most of the members } \\
\text { contribute with } \\
\text { creative or original } \\
\text { ideas. } \\
\text { Not every member } \\
\text { tries to motivate the } \\
\text { whole group, but all } \\
\text { of them have a } \\
\text { positive attitude. } \\
\text { All the members meet } \\
\text { regularly. }\end{array}$ & $\begin{array}{l}\text { The group is not } \\
\text { integrated nor designs } \\
\text { their own resources, } \\
\text { or their material was } \\
\text { not homemade. Most } \\
\text { of the tasks or roles } \\
\text { are neither equally nor } \\
\text { clearly distributed. } \\
\text { Most of the members } \\
\text { do not contribute with } \\
\text { their ideas. } \\
\text { Some members do not } \\
\text { even try to motivate } \\
\text { the rest of the group } \\
\text { nor have a positive } \\
\text { attitude. } \\
\text { Some members [or all } \\
\text { of them] do not meet } \\
\text { regularly nor prepare } \\
\text { work at home. }\end{array}$ \\
\hline DIDACTICS & $\begin{array}{l}\text { All the members } \\
\text { correctly refer to the } \\
\text { framework } \\
\text { surrounding } \\
\text { Education at different } \\
\text { levels (CEFR, the } \\
\text { Spanish Education } \\
\text { Act-LOE- and }\end{array}$ & $\begin{array}{l}\text { All the members are } \\
\text { familiar with the } \\
\text { framework } \\
\text { surrounding } \\
\text { Education at different } \\
\text { levels (CEFR, the } \\
\text { Spanish Education } \\
\text { Act -LOE- and }\end{array}$ & $\begin{array}{l}\text { All the members } \\
\text { partly know the } \\
\text { framework } \\
\text { surrounding } \\
\text { Education at different } \\
\text { levels (CEFR, the } \\
\text { Spanish Education } \\
\text { Act-LOE- and }\end{array}$ & $\begin{array}{l}\text { Most of the members } \\
\text { do not know the } \\
\text { framework } \\
\text { surrounding } \\
\text { Education at different } \\
\text { levels (CEFR, the } \\
\text { Spanish Education } \\
\text { Act -LOE- and }\end{array}$ \\
\hline
\end{tabular}




\begin{tabular}{|c|c|c|c|c|}
\hline & $\begin{array}{l}\text { regional curriculum - } \\
\text { Decree 68/2007). } \\
\text { The project coherently } \\
\text { meets national and } \\
\text { regional curricula } \\
\text { (especially objectives, } \\
\text { competences and } \\
\text { results) suitable for } \\
\text { the second cycle of } \\
\text { Primary, for } 4^{\text {th }} \text { grade } \\
\text { in particular. } \\
\text { All the members } \\
\text { perfectly integrate } \\
\text { their knowledge into } \\
\text { their projects and } \\
\text { class units. } \\
\text { The activities } \\
\text { proposed are suitable } \\
\text { for the assigned topic, } \\
\text { the level of the } \\
\text { different students and } \\
\text { the design of the } \\
\text { lesson plan. } \\
\text { The project covers the } \\
\text { five skills (oral } \\
\text { interaction, } \\
\text { production, listening, } \\
\text { reading and writing) } \\
\text { coherently. }\end{array}$ & $\begin{array}{l}\text { regional curriculum - } \\
\text { Decree } 68 / 2007) \text {. } \\
\text { The project meets } \\
\text { national and regional } \\
\text { curricula suitable for } \\
\text { the second cycle of } \\
\text { Primary, for } 4^{\text {th }} \text { grade } \\
\text { in particular. } \\
\text { All the members } \\
\text { mostly integrate their } \\
\text { knowledge into their } \\
\text { projects and class } \\
\text { units. } \\
\text { The activities } \\
\text { proposed are quite } \\
\text { suitable for the } \\
\text { assigned topic, the } \\
\text { level of the different } \\
\text { students and the } \\
\text { design of the lesson } \\
\text { plan. } \\
\text { The project covers } \\
\text { most of the five skills } \\
\text { coherently. }\end{array}$ & $\begin{array}{l}\text { regional curriculum - } \\
\text { Decree 68/2007). } \\
\text { The project fairly } \\
\text { meets national and } \\
\text { regional curricula } \\
\text { suitable for the second } \\
\text { cycle of Primary. } \\
\text { All the members } \\
\text { integrate their } \\
\text { knowledge into their } \\
\text { projects and class } \\
\text { units although some } \\
\text { little mistakes are } \\
\text { noticed. } \\
\text { The } \\
\text { proposed are suitable } \\
\text { for the assigned topic } \\
\text { and the level of the } \\
\text { different students, but } \\
\text { not to the design of } \\
\text { the lesson plan. } \\
\text { The project does not } \\
\text { cover the five skills, } \\
\text { but the ones chosen } \\
\text { are } \\
\text { coherently. }\end{array}$ & $\begin{array}{l}\text { regional curriculum - } \\
\text { Decree } 68 / 2007) \text {. } \\
\text { The project does not } \\
\text { meet national and } \\
\text { regional curricula, or } \\
\text { it is not suitable either } \\
\text { for the second cycle } \\
\text { of Primary or for } 4^{\text {th }} \\
\text { grade in particular. } \\
\text { Most of the members } \\
\text { do not integrate their } \\
\text { knowledge into their } \\
\text { projects or class units. } \\
\text { The activities } \\
\text { proposed are not } \\
\text { suitable for the } \\
\text { assigned topic, the } \\
\text { level of the different } \\
\text { students nor the } \\
\text { design of the lesson } \\
\text { plan. } \\
\text { The project does not } \\
\text { cover the five skills } \\
\text { coherently or the ones } \\
\text { chosen are not worked } \\
\text { correctly. }\end{array}$ \\
\hline $\begin{array}{c}\text { ENGLISH } \\
\text { LANGUAGE }\end{array}$ & $\begin{array}{l}\text { There are neither } \\
\text { spelling, grammar } \\
\text { mistakes nor } \\
\text { punctuation errors. } \\
\text { The meaning of the } \\
\text { subtitles is correct. } \\
\text { All the members } \\
\text { speak English fluently } \\
\text { taking into account }\end{array}$ & $\begin{array}{l}\text { There are minor } \\
\text { spelling or grammar } \\
\text { mistakes, but there } \\
\text { are not punctuation } \\
\text { errors. } \\
\text { The meaning of the } \\
\text { subtitles is quite } \\
\text { correct. } \\
\text { Most of the members }\end{array}$ & $\begin{array}{l}\text { There are little } \\
\text { spelling, grammar } \\
\text { mistakes } \\
\text { punctuation errors. } \\
\text { The meaning of the } \\
\text { subtitles is correct } \\
\text { most of the times. } \\
\text { Most of the members } \\
\text { try to speak English }\end{array}$ & $\begin{array}{l}\text { There are both } \\
\text { spelling and grammar } \\
\text { mistakes, and } \\
\text { punctuation errors. } \\
\text { The meaning of the } \\
\text { subtitles is not } \\
\text { [always] correct. } \\
\text { Most of the members } \\
\text { do not speak English }\end{array}$ \\
\hline
\end{tabular}




\begin{tabular}{|c|c|c|c|c|}
\hline & $\begin{array}{l}\text { phonetic aspects such } \\
\text { as rhythm, stress and } \\
\text { intonation. }\end{array}$ & $\begin{array}{l}\text { speak English } \\
\text { fluently taking into } \\
\text { account almost all the } \\
\text { phonetic aspects. }\end{array}$ & $\begin{array}{l}\text { fluently taking into } \\
\text { account phonetic } \\
\text { aspects. }\end{array}$ & $\begin{array}{l}\text { fluently or do not take } \\
\text { into account phonetic } \\
\text { aspects. }\end{array}$ \\
\hline $\begin{array}{c}\text { ICT AND } \\
\text { SUBTITLING }\end{array}$ & $\begin{array}{l}\text { All the subtitling } \\
\text { norms are perfectly } \\
\text { applied (no more than } \\
\text { two lines at a time, } 35 \\
\text { characters max., } \\
\text { remaining on the } \\
\text { screen } 2-7 \text { secs.). } \\
\text { The subtitles are well } \\
\text { placed } \\
\text { synchronized. } \\
\text { The principle of } \\
\text { maximum legibility is } \\
\text { fulfilled taking into } \\
\text { account the target } \\
\text { audience (8-year- } \\
\text { olds). } \\
\text { All the members } \\
\text { manage slide } \\
\text { presentations at an } \\
\text { advanced level. } \\
\text { All the members } \\
\text { handle specific } \\
\text { an advanced level. }\end{array}$ & $\begin{array}{l}\text { All the subtitling } \\
\text { norms are applied but } \\
\text { some little mistakes } \\
\text { are noticed. } \\
\text { The subtitles are well } \\
\text { placed and } \\
\text { synchronized most of } \\
\text { the times. } \\
\text { The principle of } \\
\text { maximum legibility is } \\
\text { fulfilled. } \\
\text { All the members } \\
\text { manage slide } \\
\text { presentations at an } \\
\text { intermediate level. } \\
\text { All the members } \\
\text { handle specific } \\
\text { software, subtitling } \\
\text { tools and formats at } \\
\text { an intermediate level, } \\
\text { or most of them at an } \\
\text { advanced level. }\end{array}$ & $\begin{array}{l}\text { All the subtitling } \\
\text { norms are applied but } \\
\text { one. } \\
\text { There are some } \\
\text { mistakes } \\
\text { placing } \\
\text { synchronizing the } \\
\text { subtitles. } \\
\text { Most of the times, the } \\
\text { principle of maximum } \\
\text { legibility is noticed. } \\
\text { All the members } \\
\text { manage slide } \\
\text { presentations at an } \\
\text { elementary level. } \\
\text { All the members } \\
\text { handle specific } \\
\text { software, subtitling } \\
\text { tools and formats at } \\
\text { an elementary level. }\end{array}$ & $\begin{array}{l}\text { There are serious } \\
\text { mistakes regarding the } \\
\text { subtitling norms. } \\
\text { The subtitles are not } \\
\text { well placed or } \\
\text { synchronized. } \\
\text { The principle of } \\
\text { maximum legibility is } \\
\text { not considered. } \\
\text { Most of the members } \\
\text { do not manage slide } \\
\text { presentations. } \\
\text { Most of the members } \\
\text { can hardly handle } \\
\text { specific software, } \\
\text { subtitling tools and } \\
\text { formats. }\end{array}$ \\
\hline
\end{tabular}


Annex 2: Cooperative group report (individual)

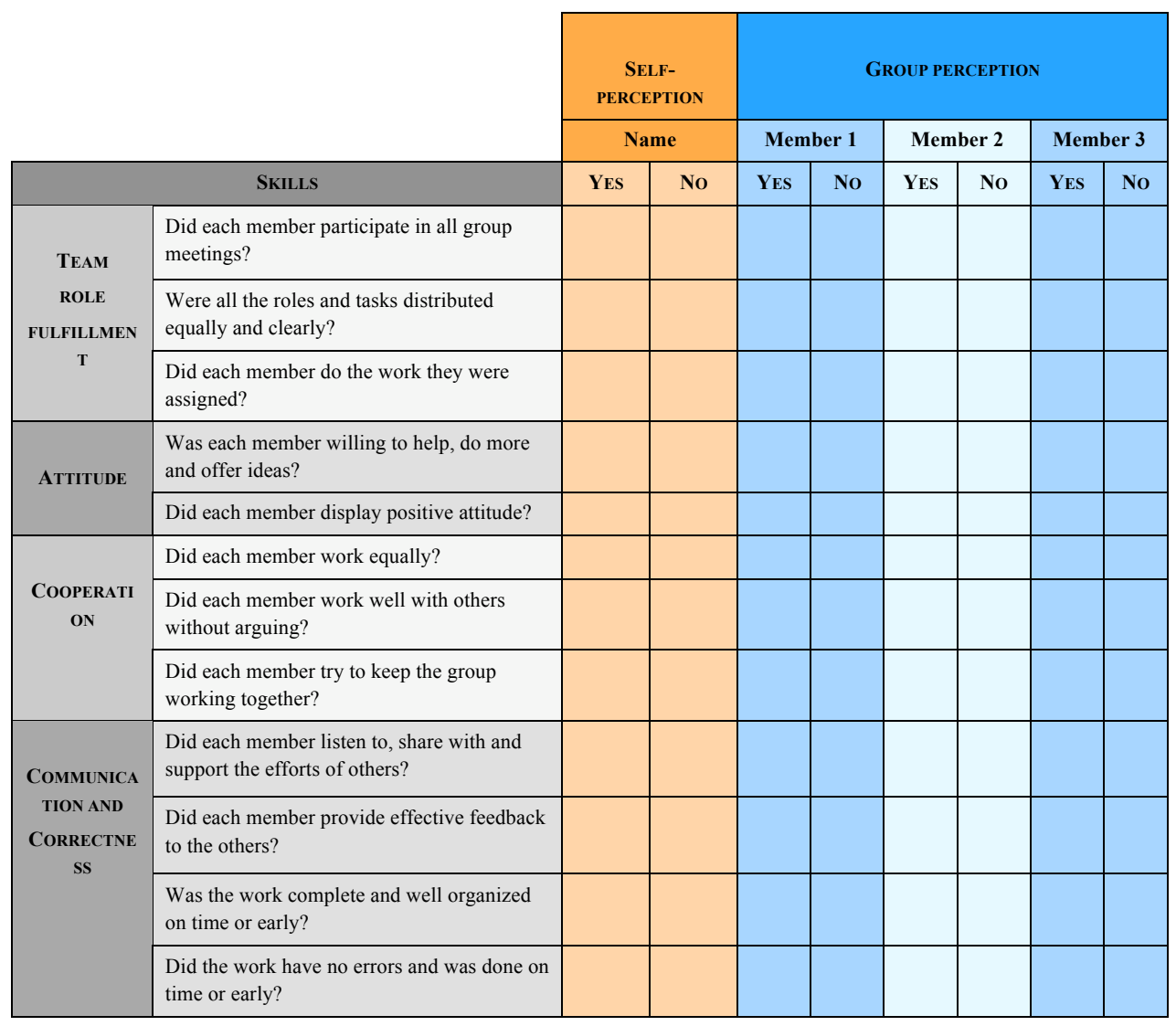




\section{Annex 3: Project evaluation report (groupal)}

\begin{tabular}{|c|c|c|c|c|c|c|c|c|c|}
\hline \multirow[b]{2}{*}{ Stage } & \multirow[b]{2}{*}{ INDICATORS } & \multicolumn{2}{|c|}{ Member 1} & \multicolumn{2}{|c|}{ Member 2} & \multicolumn{2}{|c|}{ Member 3} & \multicolumn{2}{|c|}{ Member 4} \\
\hline & & YES & No & YES & No & Yes & No & YeS & No \\
\hline \multirow{4}{*}{$\begin{array}{c}\text { INITIAL } \\
\text { STAGE }\end{array}$} & $\begin{array}{l}\text { Was your group successfully formed? Did all } \\
\text { the members agree to work together? }\end{array}$ & & & & & & & & \\
\hline & $\begin{array}{l}\text { Did all the members agree to the topic they } \\
\text { were assigned? }\end{array}$ & & & & & & & & \\
\hline & Were you happy about your topic? & & & & & & & & \\
\hline & $\begin{array}{l}\text { ANSWER WITH YOUR OWN WORDS: What } \\
\text { was the most difficult part at this stage? } \\
\text { Would you change anything in it? }\end{array}$ & & & & & & & & \\
\hline \multirow{6}{*}{$\begin{array}{l}\text { RESEARCHING } \\
\text { STAGE }\end{array}$} & $\begin{array}{l}\text { Did all the members search for materials and } \\
\text { bibliography both on the legal Education } \\
\text { framework in Castilla-La Mancha, Spain and } \\
\text { Europe, and on English teaching in Primary? }\end{array}$ & & & & & & & & \\
\hline & $\begin{array}{l}\text { Did all the members search for software } \\
\text { tutorials and forums? }\end{array}$ & & & & & & & & \\
\hline & $\begin{array}{l}\text { Did all the members attend the workshops on } \\
\text { subtitling and ICT? }\end{array}$ & & & & & & & & \\
\hline & $\begin{array}{l}\text { Did all the members help select the tales, } \\
\text { characters, setting and/or stories? }\end{array}$ & & & & & & & & \\
\hline & $\begin{array}{l}\text { Did all the members provide ideas and } \\
\text { solutions to the problems? }\end{array}$ & & & & & & & & \\
\hline & $\begin{array}{l}\text { ANSWER WITH YOUR OWN WORDS: What } \\
\text { was the most difficult part at this stage? } \\
\text { Would you change anything in it? }\end{array}$ & & & & & & & & \\
\hline \multirow{8}{*}{$\begin{array}{l}\text { Production } \\
\text { Stage }\end{array}$} & $\begin{array}{l}\text { Were the script, characters and/or drawings, } \\
\text { storyboard and story suitably planned before } \\
\text { being written? }\end{array}$ & & & & & & & & \\
\hline & $\begin{array}{l}\text { Was the story in accordance to the topic, } \\
\text { level and the above mentioned items? Was } \\
\text { the story ordered in a logical way? }\end{array}$ & & & & & & & & \\
\hline & $\begin{array}{l}\text { Were linguistic and cultural limitations of } \\
\text { English knowledge of fourth graders in } \\
\text { Primary considered? }\end{array}$ & & & & & & & & \\
\hline & $\begin{array}{l}\text { In the case of videos, was the recording } \\
\text { location chosen taking into account the } \\
\text { quality of space, light and noise? }\end{array}$ & & & & & & & & \\
\hline & Was the material fully in English? & & & & & & & & \\
\hline & $\begin{array}{l}\text { Were the intralingual English subtitles } \\
\text { added? }\end{array}$ & & & & & & & & \\
\hline & $\begin{array}{l}\text { ANSWER WITH YOUR OWN WORDS: What } \\
\text { was the most difficult part at this stage? } \\
\text { Would you change anything in it? }\end{array}$ & & & & & & & & \\
\hline & $\begin{array}{l}\text { Were all the parts of the project saved in the } \\
\text { appropriate formats? }\end{array}$ & & & & & & & & \\
\hline
\end{tabular}




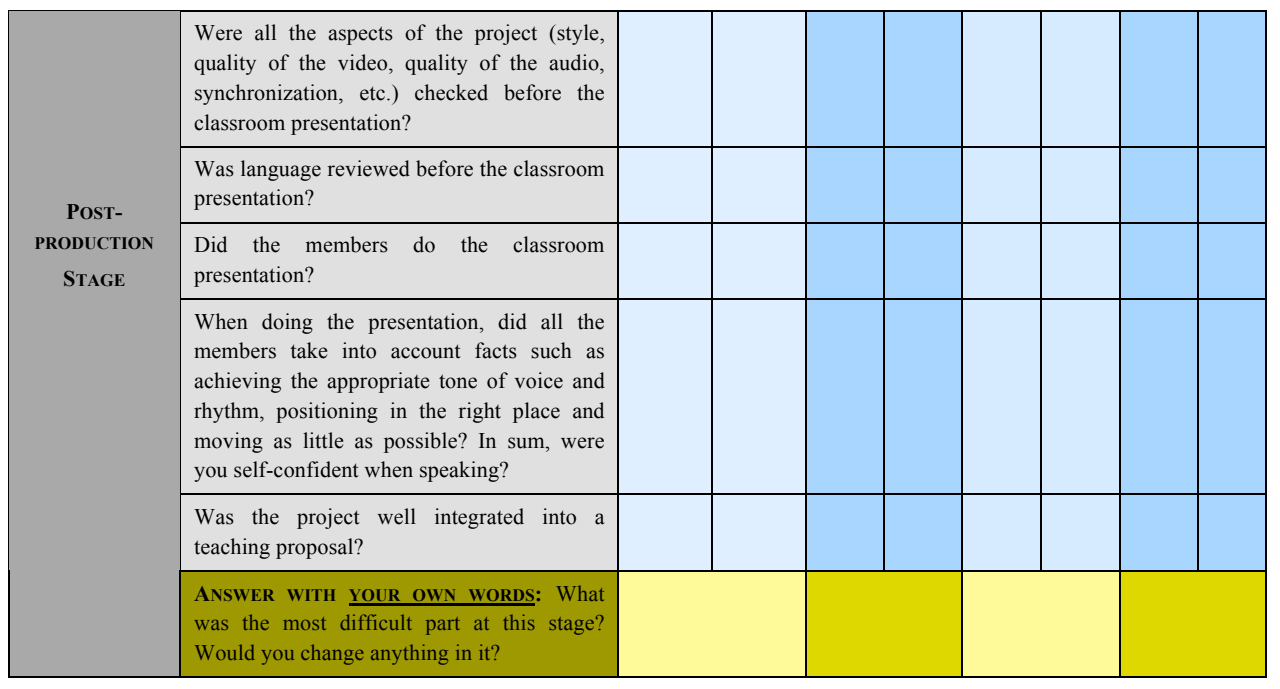

